\title{
Technological stress in higher level students in San Luis Potosí
}

\section{Estrés tecnológico en estudiantes de nivel superior en San Luis Potosí}

\author{
HUERTA-GONZÁLEZ, Juana Maríał*, MARTÍNEZ-TORRES, Rosa Elia, RIVERA-ACOSTA, \\ Patricia and RENDÓN-SUSTAITA, Gloria Del Carmen
}

Tecnológico Nacional de México, Instituto Tecnológico de San Luis Potosí.

ID $1^{\text {st }}$ Author: Juana María, Huerta-González / ORC ID: 0000-0003-0434-2115, CVU CONACYT ID: 1138959

ID $1^{\text {st }}$ Co-author: Rosa Elia, Martínez-Torres / ORC ID: 0000-0001-8936-9207, CVU CONACYT ID: 953355

ID $2^{\text {nd }}$ Co-author: Patricia, Rivera-Acosta / ORC ID: 0000-0002-8254-0005, CVU CONACYT ID: 232611

ID $3^{\text {rd }}$ Co-author: Gloria del Carmen, Rendón-Sustaita / ORC ID: 0000-0003-7769-5491, CVU CONACYT ID: 610903

DOI: 10.35429/JHEW.2021.9.5.1.8

Received July 10, 2021; Accepted December 30, 2021

\begin{abstract}
During 2020, in the face of the recession caused by the COVID19 pandemic, public and private sectors suffer massive losses that force them to promote strategies for immediate reactivation. Education in México, despite estimating a considerable lag, had a favorable reaction towards "online classes" in all education levels. Through technological resources, administrative, teachers, parents and students were involved without having the opportunity to be questioned. As a result of this, a study was proposed with a quantitative approach and descriptive method, to keep record of the effects presented by college students before this modality. Natural stress is associated with social isolation through dimensions involving ICTs with the aim of diagnosing the personal, family, social and technological impact on college students in San Luis Potosí, to determine the effects that are adverse to their learning and professional life. The results will contribute to the development of strategies associated with the effective use of the ICTs that institutions offer and facilitate the teaching-learning process; the study also concluded according to the integral well-being of the student in this new modality.
\end{abstract}

\section{Resumen}

Durante 2020, frente a la recesión causada por la pandemia COVID19, sectores públicos y privados, sufren fuertes pérdidas que los obliga a promover estrategias de reactivación inmediata. La Educación en México, a pesar de estimar un rezago considerable, tuvo una favorable reacción hacia las "clases en línea" en todos los niveles. A través de recursos tecnológicos, administrativos, docentes, padres de familia y estudiantes, se vieron involucrados sin tener la oportunidad de ser cuestionados. Derivado de ello, se planteó un estudio con enfoque cuantitativo y método descriptivo, para documentar efectos presentados por estudiantes de nivel superior ante esta modalidad. Se identifica el estrés natural asociado por el confinamiento a través de dimensiones que involucran las TICs con el objetivo de Diagnosticar el impacto personal, familiar, social y tecnológico en los estudiantes de nivel superior en San Luis Potosí, para determinar los efectos que sean adversos a su aprendizaje y formación profesional. Los resultados contribuyen al desarrollo de estrategias asociadas con el uso eficaz de las TIC que las instituciones ofrecen y facilitar así el proceso de enseñanza aprendizaje; se concluye además en función del bienestar integral del estudiante ante esta nueva modalidad.

Educación en línea, TIC, Estrés educativo

Citation: HUERTA-GONZÁLEZ, Juana María, MARTÍNEZ-TORRES, Rosa Elia, RIVERA-ACOSTA, Patricia and RENDÓN-SUSTAITA, Gloria Del Carmen. Technological stress in higher level students in San Luis Potosí. Journal-Health Education and Welfare. 2021. 5-9:1-8

\footnotetext{
* Correspondence to Author (Email: juana.hg@ @lp.tecnm.mx)

$\dagger$ Researcher contributing as first author.
} 


\section{Introduction}

The new normality after COVID-19 makes online education evident, breaking paradigms of traditional school systems, using information and communication technologies (ICT) facilitating learning interaction with technological resources. In Mexico there are 87.4 million internet users from the age of six, which represents $74 \%$ of the population in that age range, of which $51 \%$ are women and $49 \%$ men, in Mexico there are 18.3 million households with internet through Wi-Fi or mobile connection, in 2019 the national total was $56.4 \%$, which means an increase of $3.5 \%$ compared to 2018 (INEGI, SCT, IFT, 2019).

The incorporation of ICT in various context of the human being has implied a change in communication processes, before the pandemic, teachers were only contacted at the educational institution, however, currently, with the use of the cell phone, e-mails, social networks and work from virtual environments, teachers can be contacted inside and outside school, expanding communication time between students and teachers, which dilutes the line that exists between the academic field and personal space (Alfaro, 2009).

With the COVID-19 pandemic, teachers, students, administrative staff and parents have faced to the use of technological tools to perform work- related actions and academic activities, stress is derived for teachers and students for the use of information technologies and communication in the teaching process, learning by providing quick answers with the use of instant messaging, and email through educational platforms, most of the time inside and outside working hours causing exhaustion, worry, depression, headache, bad mood and muscle tension.

\section{Technostress, is defined as}

"a negative psychological state and an adaptative response caused by the excessive use of the information and communication technology (ICT) and the lack of handle or work with them in a healthy way" (Patlán s/f, quoted in Olvera, 2017).
This type of stress occurs more often in college students being a process of physical and mental effort; psychologically the school demands are perceived as stressful environments that affect in academic development becoming a process of spoilage in the use of the ICT.

This research aims to identify factors and levels of technological stress regarding confinement that college students from San Luis Potosí capital are presenting from universities Institute Tecnológico of San Luis Potosí, University Autónoma of San Luis Potosí, University Politécnica campus San Luis, Institute Tecnológico Superior of San Luis Potosí; This study is experimental, descriptive, quantitative to a non-probability sample of convenience, information was obtained through the application of technological stress questionnaire adapted from López (2018), in which were analyzed the following dimensions: attitude towards ICT, school or work stress, ICT effects and social media, ICT and education. Results contribute to the development of strategies associated with the effective use of ICT that are offer by institutions and facilitate the process of teaching and learning that contributes in the integral wellness from students in the new normality.

\section{Literary basis}

In precise terms, for Trianes, Fernandez, Escobar and Maldonado, (2012), school stress could impact students and teachers, regardless of the educational level they belong, but there are also some types of stress that are associated with the excessive use of ICT, either through mobile devise exposure, computers or any other gadget that facilitates its application; Remon, B (2012) some of them are:

Techno-anxiety recognized as an unpleasant feeling of tension and discomfort for the use of technology.

Technological stress, where the person perceives high levels of physiological activation uncomfortable presenting tension due to the use of some type of ICT, reflected in fear, anxiety, insecurity regarding the use of the resource. 
Technophobia that focuses on the affective dimension of fear and anxiety towards ICT, three dimensions are defined: (a) endurance to talk about technology or think about it; (b) fear or anxiety about technology; (c) hostile and aggressive thoughts towards technology.

Techno fatigue recognized by the appearance of mental fatigue and inability to structure and assimilate new information from the internet described by skeptical attitudes, emotions of weakness and mental exhaustion and cognitive due to the use of technologies with the use of ICT.

Techno addiction, which is regarded as the uncontrollable need to always use technology and places.

Techno dependence, stress related to compulsive use of ICT.

López (2018), considers technostress as a feeling of incapacity to achieve a satisfactory degree domain of technology, while in other types of users generates a certain degree of dependence on its use. The user has symptoms such as irritability when receiving instructions, Alfaro (2009), establishes four dimensions:

Attitude towards ICT, referring to an acceptance or rejection rate. This attitude of rejection can be due to dysfunctional behavior patterns. In this sense Brod (1984) points out that those who reject technology have some fear of feeling threatened, stressed and furious about machines, that do activities that they would take hours to do.

- Work or school stress translating it as the discomfort that the student presents due to physical factors, emotional or environmental factors that have significant pressure on individual competence to face school context.

Social networks and ICT, recurses that are used in education, defined as a support tool in leaning. Among the common social networks are WhatsApp, Facebook, Twitter, YouTube, Instagram, etc., not referring to any other social network created for educational purposes.
- $\quad$ Effects of the use of the ICT, recognized for the negative effects of the use of ICT.

Salanova, Llorens, Cifre and Nogareda, (2017), explain that ICTs by themselves are neutral, they do not generate positive or negative effects, however, when they relate to the subject this is when negative effects such as: anxiety (techno-anxiety) and even mental fatigue or exhaustion (techno-fatigue); recently another phenomenon has been observed relating to damage psychosocial related to the use of ICT such as addiction to technologies, Internet, e-mail, mobile.

\section{Developing}

A quantitative study with mixed approach is presented, with a descriptive correlational character, transactional and non-experimental to a non-probabilistic convenience sample of 382 students. The questionnaire was adapted from López (2018): Technological Stress questionnaire, which refers to this dimension: Attitude towards ICT (AFT), work or school stress (ELE), effects of ICT use (EUTIC) and, social media, ICT in education (RSYTIC); their interpretation is expressed on the basis of a ordinal scale of type Likert, with intervals of affirmations.

A statistical analysis was performed with which internal consistency was tested and validity of the instrument. The sample was made up for a total of 382 college students of public universities in the capital of state San Luis Potosí, $41 \%$ are men and 59\% women:

Instituto Tecnólogico of San Luis Potosí,
representing $51 \%$ of bachelor's in
administration, business management's
engineering, Engineering in
mechatronics, computer systems
engineering, Informatics engineering;

Instituto Tecnológico Superior of San Luis Potosí representing a total of $14 \%$ of the careers of engineering in administration, industrial engineering, Mechatronics engineering, Computer systems engineering. 
- Universidad Autónoma of San Luis Potosí, representing $18 \%$ of Anthropology, Architecture, Accounting, Industrial design, Physiotherapy, Environmental engineering, Biomechanical engineering, Civil Engineering, Food Engineering, Chemical engineering, Medicine, Veterinary medicine and zootechnics, Psychology, Pharmacobiologist chemist, careers.

Universidad Politécnica of San Luis Potosí, representing $17 \%$ of Engineering in systems and industrial technologies, Engineering of technology information, Manufacturing technology engineering, bachelor's in administration and Management and International marketing careers.

Based on formulated hypotheses, results that allow fulfillment of the objective of the study are categorized; through analysis of student responses about of the standard deviations for the dimensions considered to represent technostress.

\section{Results}

The ages are between 18 and 27 years with an average of 21 years. $97 \%$ have an internet connection from home meanwhile $3 \%$ have report to not have internet at home. With confinement for school reasons $5 \%$ of students use the internet for an hour or less, and $95 \%$ use internet for 12 hours or more.

The equipment used is $12 \%$ desktop computer, $40 \%$ laptop, $0.5 \%$ tablet, $30 \%$ smartphone and, finally $16 \%$ with all the devices mentioned before. Students use for their classes the following platforms, zoom never $0.5 \%$, partially $0.26 \%$ and $99 \%$ totally, use of Google classroom platform $79 \%$ never have used it, $18.5 \%$ partially use it and $1.5 \%$ totally; use of Teams never $2 \%$ partially $4.4 \%$ and $93 \%$ totally and, Blackboard $76 \%$ never have used it, $8.9 \%$ and totally $15 \%$.

Use of moodle platform never $33 \%$, partially $23 \%$ and $44 \%$ totally.
Below is the analysis of the instrument applied under an ordinal Likert scale of intervals that uses a series of statements where a response is obtained with values; 1 completely disagree, 2 disagree, 3 neither disagree nor agree, 4 agree and 5 totally agree. Values above or below scale 3 show a positive or negative attitude, scale 3 is neutral.

\section{Dimension: Attitude towards ICT (AFT)}

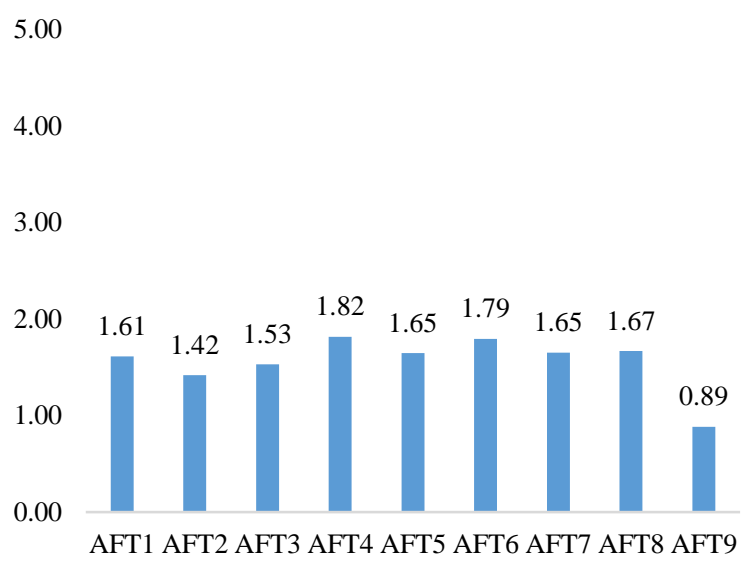

Graphic 1 AFT in time of pandemic Source: Own elaboration

As shown in graphic 1.

AFT1 Question "Over time ICTs interest me less" As a result, the weighted average of the students represents $1.61 \%$ that means they disagree with this statement due to the importance that a proactive attitude towards the use of devices has in the learning process in this pandemic.

AFT2 Question "I feel less involved in the use of ICT" The statement of the students is in disagreement which represents $1.42 \%$ because they are involved with the use of ICT.

AFT3 Question "I could do my homework or jobs without the ICT" The statement of the students is $1.53 \%$ in completely disagree because the use of them is required to fulfill academic responsibilities.

AFT4 Question "I often have a hard time sleeping when I have a lot of work related to the use of ICT" As a result, the statements represent $1.82 \%$ in completely disagree, at this time there is flexibility in both the schedules for academic obligations and even classes recordings are available to the students when they require it. 
AFT5 I find difficult to relax after a day's work using ICT.

AFT6 Question: "I am so tired when I finish working with ICT that I can't do more" As a result, the statements of the students represent $1.65 \%$ and $1.79 \%$ in completely disagree, respectively, the attitude of students is indifferent due to the adaptation of knowledge and use of ICT.

AFT7 Question "I doubt when I use technologies" As a result, the statements represent $1.65 \%$ in completely disagree this means that they are not afraid of making mistakes because they have a positive vision of trial and error and when using ICT allow them to learn new information.

AFT8. Question "Working with ICT makes me feel uncomfortable, irritable and impatient". As a result, the statements represent $1.67 \%$ completely in disagreement which means that the attitudes are positives when using ICT because you can find a diversity of information.

AFT9. Question "In my opinion I am effective using technologies" As a result, the statements represent $0.89 \%$ in completely disagree, which indicates that students do not feel effective when using technology during pandemic due to large amount of information that is available and the lack of time to analyze and synthesize the information. College students of San Luis Potosi show a moderate attitude that means they adapted to pandemic and the need of the use of connectivity, electronic devices, behavior, feelings and generate positive responses in the learning process due to pandemic.

Dimension: Work or school stress (ELE)

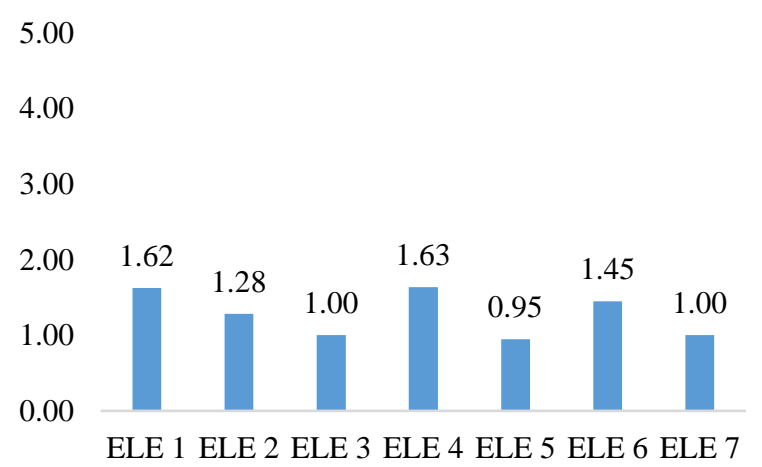

Graphic 2 ELE in time of pandemic

Source: Own elaboration
Values are observed in Graphic 2.

ELE1. Question "I get frustrated when they implement new technologies in my place of study" As a result, the statements represents $1.62 \%$ the statements are in complete disagreement because students adapt quickly to new technologies during pandemic, because most of the educational platforms have similarities in terms of accessibility and resources available for the teaching- learning process.

ELE2 Question "I have resistance to the use of technology that is supposed to improve educational processes" As a result, statements represent $1.28 \%$ in completely disagree, students are resilient they accept the circumstance and stress becomes an opportunity for the teaching-learning process.

ELE3 Question "I have multiple windows open in the browser to multitask at the same time" As a results, statements represent $1.00 \%$ completely disagree, students use a single window to do their activities because they have to focus on their classes also there are so many technological distractors in the environment so it's not convenient to have several windows open.

ELE4 Question "I need to check my cell phone notifications immediately, even if I interrupt what I'm doing" As a result, statements represent $1.63 \%$, strongly disagree students in lockdown are not aware of notifications unless they are important school notifications.

ELE5 Question "I am exposed daily to a large amount of information through ICT", statements represent $0.95 \%$ completely disagree, students are exposed to a large amount of information, however they do not show tension because they are familiar with the large amount of digital information to which they are exposed due the pandemic.

ELE6 Question "I despair if I don't have internet" As a result, the statements represent $1.45 \%$ in complete agreement, if they do not have connectivity causes tension and anguish because they cannot meet their academic obligations. 
ELE7 Question "I get annoyed when I'm with my friends and family and that's why I rather to be on the internet". The statements represent $1.00 \%$ completely disagree in fact students prefer to socialize with family and friends once they finish their academic obligations. In summary, the school or work stress symptoms are positive in their adaptation: workloads, schedules, use of devices, but there is not a psychological impact such as anxiety, depression, cognitive and social in the learning processes in the pandemic.

\section{Dimension: Effects of using ICT (EUTIC)}

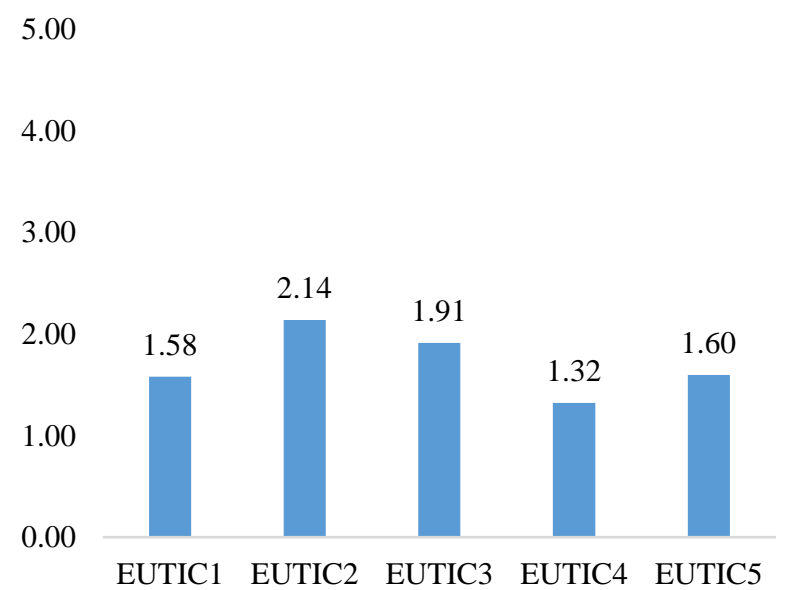

Graphic 3 EUTIC in time of pandemic Source: Own elaboration

As results observed in graphic 3 EUTIC are the following:

EUTIC 1. Question "When I use my device for online classes, I can spend hours without realizing it" As a result, statements represent $1.58 \%$ in completely disagree, in other words online classes have specific schedules and they are recorded to consult any questions, relying on platforms for academic obligations with specific dates and schedules.

EUTIC2. Question "Sometimes I forget to eat when I am using my device for school reasons" As a result, the statements represent a $2.14 \%$ in disagree which means that they can eat while they are on online classes or doing homework.

EUTIC3. Question "When I finally put turn off the device, I feel very anxious or nervous and sometimes even angry" As a result, the statements represent $1.91 \%$ in completely disagree; students are relieved to not use a device after online academic activities.
EUTIC4. Question "I fulfill all my responsibilities despite the constant use of a device" As a result, the statement represents $1.32 \%$ in completely disagree they fulfill all their activities however the use of the device is not constant.

EUTIC5. Question "On weekends I spend all day using my device" As a result, the statements represent $1.60 \%$ in completely disagree, students are tired and have no interest in using devices on the weekend. In conclusion, the dimension effects on the use of ICT because is below level 3, which indicates that the effects with the use of ICT are measured and, in the pandemic, they don't reject technology, neither they feel stressed or fatigued by the use of ICT.

Dimension: Social Networks and ICT (RSYTIC)

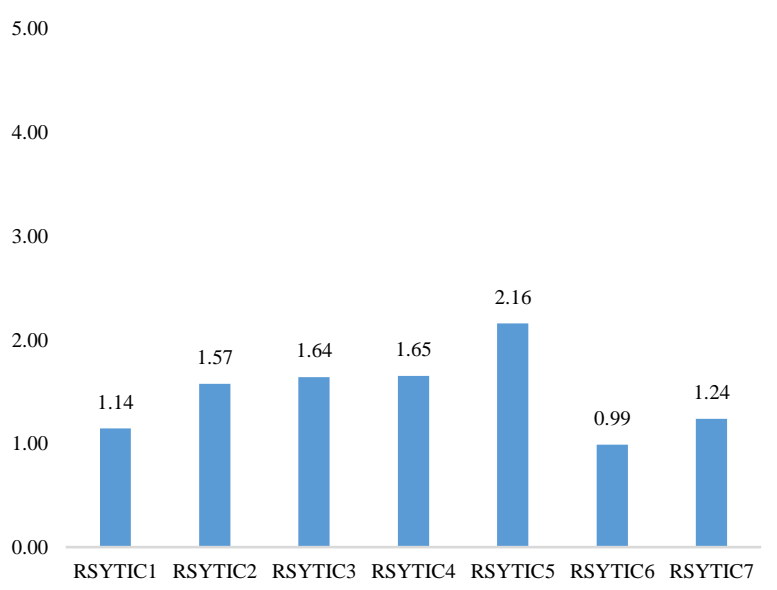

Graphic 4 RSYTIC in time of Pandemic Source: Own elaboration

The results of graphic 4 RSYTIC are described below.

RSYTIC1. Question "I use of social networks to share files, links or information about homework with my classmates" As a result, statements represent $1.14 \%$ in completely disagree, because during pandemic students use academic platforms where the activities and resources for academic activities are established.

RSYTIC2. Question "There is a social network group with the teacher for school purposes only".

RSYTIC3. Question "There is a group on common social networks with the teacher for school purposes only". 
RSYTIC4. Question "The teacher answers school questions through social networks" As a result, the statements represent $1.57 \%, 1.64 \%$ and $1.65 \%$ in completely disagree. Universities use platforms for online education such as zoom, google classroom, teams, blackboard and moodle all of them have instant messaging as a resource so teacher can give instructions, clarify doubts and students can exchange information in real time.

RSYTIC5. Question "Video calls are used as a social network to clarify school doubts" As a result, the statements represent $2.16 \%$ in disagreement they are not only used to clarify doubts but also as a part of the new normal, online teaching through videoconferences where college students connect synchronously to a virtual classroom where they have a bunch of resources, Integrated applications and can virtually interact teacher and student.

RSYTIC6. Question "My teachers use ICT for better teaching" As a result, the statements correspond to $0.99 \%$ in completely disagree, probably due to the sudden change in the modality face-to-face to online classes, and even when the teachers were trained for this modality, they have not being able to use all the resources available in educational platforms and social networks to optimize the teachinglearning process.

RSYTIC7. Question "Homework is easier when I use ICT" As a result, the statements correspond to $1.24 \%$ completely in disagree despite the facility with internet or use of devices, sometimes the activities are not correctly structured or they don't give clear specifications or a detailed rubric which causes confusion between what teacher expects from homework and what the student deliver. It ends with the analysis of the social networks and ICT dimension. Indicating that it's below scales 3.

The use of social networks and ICT is favorable at this pandemic time and the strategies adopted by colleges are accepted and don't cause stress.

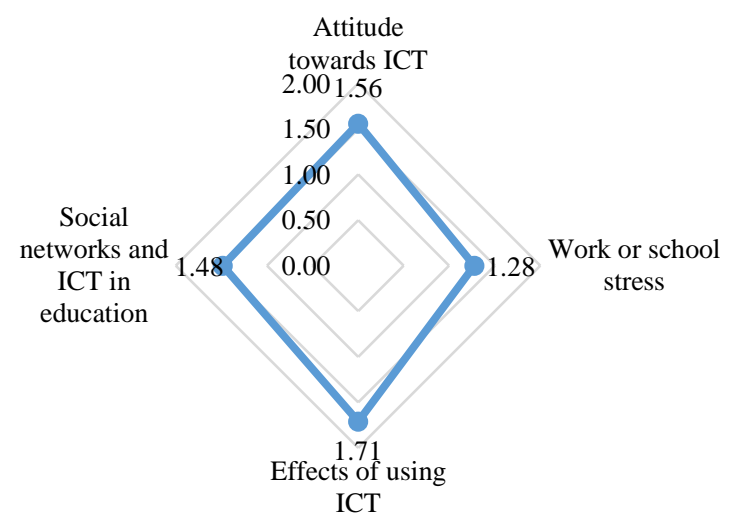

Figure 1 Techno-stress dimensions in times of pandemic Source: Own elaboration

The final result is presented as an image that concentrates the information obtained by the dimensions analyzed; with this it is possible to observe that: College students show an average of $1.56 \%$ in their attitude towards ICT, interpreted as an attitude of acceptance. The effects of the use of ICT shows an average of $1.71 \%$ as a low level, Work or school stress (ELE) oscillates at $1.28 \%$, also indicating a slight functional stress due changes in habits, social networks and ICT in education (RSYTIC) with an average of $1.48 \%$, indicating efficient use of these resources.

\section{Conclusions}

In México the inequality in access to information technology makes it impossible to access the knowledge, search and learning through ICT. The challenge is to establish public policies for infrastructure for access to information so we can take better advantage of the dynamics that are taking place in online classes.

In this study it was observed that despite the conditions due to pandemic and the use of alternative resources, college students through a sample from public universities in San Luis Potosí capital, show a positive attitude in this new normality because students have knowledge and skills in technological tools. That allow quick adaptation to tech-learning strategies and incorporated new training technologies to solve academic demands. The communication at distance became a necessity in the pandemic and to give continuity to the educational process, online education was implemented where work or school stress has a close relationship with the effects of the use of ICT.

HUERTA-GONZÁLEZ，Juana María，MARTÍNEZ-TORRES Rosa Elia, RIVERA-ACOSTA, Patricia and RENDÓNSUSTAITA, Gloria Del Carmen. Technological stress in higher level students in San Luis Potosí. Journal-Health Education and Welfare. 2021 
The digital divide and digital literacy at the moment have very significant effects on students who have moderate stress due to school. Finally, work or school stress is related to social networks and ICT in education during pandemic because students had to get used to a new learning process, which implied challenges of autonomous academic work to generate knowledge.

\section{References}

Alfaro, A., (2009). Estrés tecnológico: medidas preventivas para potenciar la calidad de vida laboral. Revista Andaluza de trabajo y bienestar social.

Hernández, T., Ávila, D., Hernández, J., y Torres, D. (2021). La Presencia de Phubbing en Estudiantes del Nivel Superior. Panorama, 15(28), 92-104.

Hernández, R., (2014). Metodología de la investigación, 6 ${ }^{\mathrm{a}}$. Edición. México: McGrawHill.

INEGI, SCT e IFT., (2019). Instituto Nacional de Estadística y Geografía, Secretaría de Comunicaciones y Transportes e Instituto Federal de Telecomunicaciones, Encuesta sobre Disponibilidad y Uso de Tecnologías de la Información y la Comunicación en los Hogares.

López, R., (2018). Encuesta Estrés Tecnológico. Colima: Universidad de Colima.

Martínez, A., Alvarado, F., Neri, J., Castañeda, R., y Reynoso, C. (2020). Prácticas de innovación educativa en IES ante la contingencia sanitaria del 2020: Estudio de caso. Efectos sociales, económicos, emocionales y de la salud ocasionados por la pandemia del COVID19, 231.

Olvera, L., (2017). Tecnoestrés, efecto del uso excesivo de las TIC. La Gaceta Digital UNAM. Recovered from: http://www.gaceta.unam.mx/20170516/tecnoest res-efecto-del-usoexcesivo-de-las-tic/

Remón, B., (2012). Consecuencias del trabajo emocional. Dpto. de Prevención de Confederación de Empresarios de Navarra.

Salanova, M., Llorens, S., Cifre, E., y Nogareda, C., (2007). Tecnoestrés; concepto, medida e intervención psicosocial
Tandazo, L., y Erreyes, H.. (2021). Didáctica virtual y desempeño académico en estudiantes de maestrías de educación de la PUCEAmbato. Horizontes. Revista de Investigación en Ciencias de la Educación, 5(17), 252-276.

Trianes, B., Fernández, F., Escobar, M., y Maldonado, E., (2012). Evaluación y tratamiento del estrés cotidiano en la infancia. Papeles del Psicólogo.
HUERTA-GONZÁLEZ，Juana María，MARTÍNEZ-TORRES, Rosa Elia, RIVERA-ACOSTA, Patricia and RENDÓNSUSTAITA, Gloria Del Carmen. Technological stress in higher level students in San Luis Potosí. Journal-Health Education and Welfare. 2021 